\title{
TEST OF COTTON LINES WITH DROUGHT TOLERANT INTERCROPPED WITH MAIZE
}

\author{
Kadarwati Fitriningdyah Tri*, Khuluq Ahmad Dhiahul \\ Indonesian Sweetener and Fiber Crops Research Institute, Indonesia \\ *E-mail: fitriningdyah@gmail.com
}

\begin{abstract}
The distribution of cotton cultivation is mostly located in the sub-optimal land due to competition with the field crop. The cotton cultivation in Indonesia is always done through intercropping with pulses. This research aims to test the suitability of cotton lines with drought-tolerant intercropped with maize. The research is conducted in February to August 2016 at Asembagus Experimental Garden, Situbondo. Planting materials used in this research are 6 lines and 2 varieties of drought-tolerant cotton consist of strain 03001/9, 03008/24, 03008/25, 03017/13, 06062/3, 06063/3, kanesia 10 and kanesia 14. The research prepared by the draft randomized group with three replications. The observation parameter consists of plant height, canopy width, number of generative branches, number of fruits, fruits weight, the yield of seed cotton, and corn dry results. The research result shows that the strain 03017/13 and 03008/24 have the highest consecutive acceptance of IDR 17,860,681 and IDR 17,520,879, the increase in revenue compared to monoculture is IDR 6,278,473 and IDR $5,668,191$, seed cotton production amounted to $2470.01 \mathrm{~kg} / \mathrm{ha}$ and $2329.72 \mathrm{~kg} / \mathrm{ha}$, maize production amounted to $2001.54 \mathrm{~kg} / \mathrm{ha}$ and $2112.74 \mathrm{~kg} / \mathrm{ha}$, LER 1.68 and 1.60 , number of harvested fruit of 12.66 and 11.76 fruits/plant, fruit weight of 4.05 and $4.17 \mathrm{~g} / \mathrm{fruit}$.
\end{abstract}

\section{KEY WORDS}

Intercropping, cotton, corn, field study, variety.

Cotton is an important plantation commodity in Indonesia to support the growing textile industry. Cotton is also a strategic commodity because it is used as one of the raw materials of bank notes. The cotton fibers are considered to be more flexible and not easy to damage. Furthermore, it is more resistant to the possibility of being doodled and will not be damaged by ironing (KOMPAS, 2016). The national cotton area in 2014 is 3,670 ha with a national production of 761 tons. The width distributions of national cotton planting by province and cultivation status in 2014 are Central Java (154 ha), Jogjakarta (18 ha), East Java (336 ha), Bali (150 ha), West Nusa Tenggara (136 ha), East Nusa Tenggara (63 ha) and South Sulawesi (2813 ha). While the national cotton imports in 2014 amounted to 711,744 tons (Dirjenbun, 2015). The increasing area of cultivation and productivity of cotton is still needed to meet the national cotton needs.

Cotton cultivation in Indonesia is always carried out through intercropping with palawija such as soybeans, maize, or green beans, and both in the rain-fed field or in the field after being used to plant rice. Cotton is only cultivated by intercropping or relay cropping with palawija as complementary crop instead of the main crop (Basuki et al., 2007). The selection of the type of palawija depends on the farmer's selection or the palawija that grows on the site. Generally, the type of plants that are intercropped has different age so that the peak of nutritional, water and light needs are also different and this will decrease the level of competition among the crops (Sullivan, 2003). After the palawija is harvested with the shorter age of plants comparing to cotton, the cotton crops will have enough time to grow and develop after the harvesting of the palawija.

The distribution of cotton cultivation is widely available in sub-optimal land due to competition with the field crops that is widely cultivated in the rice field. Thus, it requires cotton strains that has resistance to drought stress condition with limited water availability in order to obtain good cotton productivity. Besides, the effort to improve the farmer's income as well as reduce the risk of cotton harvesting failure can be achieved by using intercropping system between cotton and palawija. The recommended palawija corps are green beans, 
soybeans, or maize adapted to the development area. Therefore, the testing of cotton strain with drought tolerant on the suitability of intercropping pattern should be done in order to know how much the productivity of intercropped cotton produced and the increase in the farmer's income generated from the intercropping activity with palawija.

\section{MATERIALS AND METHOD OF RESEARCH}

The research is conducted in February until August 2016 at Asembagus Experimental Garden (KP), Situbondo Regency, Indonesia. The planting materials used in this research are 6 strains of cotton crossing between cotton strains with drought-resistant character. Strain crossing was conducted from 1997 until 2006 and drought tolerant testing had been done in screen house in 2014. As the comparison, 2 varieties of cotton have been selected namely Kanesia 10 and Kanesia 14 with drought tolerant.

The study is arranged in a randomized group design with three replications. A cotton intercropping system with maize uses 3:2 cropping system and 2 lines of maize (Riajaya and Kadarwati, 2005). Cotton and maize cultivation in the intercropping system or monoculture is done at the same time. The size of per plot of the experiment was $18.5 \mathrm{~m} \mathrm{x} 7 \mathrm{~m}$ with the provision of spacing on the intercropping of cotton of $100 \mathrm{~cm} \times 12 \mathrm{~cm}$ with the plant spacing of cotton-maize of $50 \mathrm{~cm}$ and the plant spacing of maize intercropping of $70 \mathrm{~cm} \times 20 \mathrm{~cm}$. Meanwhile, the plant spacing of cotton monoculture is $100 \mathrm{~cm} \times 25 \mathrm{~cm}$ and the plant spacing of maize monoculture is $70 \mathrm{~cm} \times 20 \mathrm{~cm}$.

The monoculture of cotton and soybean is used to count the decrease of cotton or maize yield to the intercropping of cotton+maize. The maize variety used is hybrid corn of double cross variety. While the comparative strain and varieties used are as follows:

1. Strain 03001/9 (DPX 7062-7077 X MYSORE VIJAYA);

2. Strain 03008/24 (NUCOTN35B X MYSORE VIJAYA);

3. Strain 03008/25 (NUCOTN35B X MYSORE VIJAYA);

4. Strain 03017/13 (NUCOTN35B X LAXMI);

5. Strain 06062/3 (KANESIA $7 \times$ KI.502);

6. Strain 06063/3 (KANESIA 8 X KI.42);

7. KANESIA 10 variety (comparison);

8. KANESIA 14 variety (comparison).

The observations done to the cotton crops are plant height, canopy width, number of generative branches, number of fruits, number of harvested fruits, fruits weight, and seed cotton production. While the observations on maize plant are: plant height, canopy width, and corn dry results. The obtained data will be analyzed using analysis of variance (ANOVA) with SAS and follow-up test will be conducted using DMRT 5\%.

\section{RESULTS AND DISCUSSION}

In general, the cotton cultivation condition in the intercropping pattern of cotton+maize is quite good as shown by the cotton height of 60 dap ranging from $103.2 \mathrm{~cm}$ to $119.4 \mathrm{~cm}$. While the height of maize ranging from $165.7 \mathrm{~cm}$ to $181.1 \mathrm{~cm}$. In the cotton monoculture cultivation, it is obtained the plant height ranging from $90.9 \mathrm{~cm}$ to $104.4 \mathrm{~cm}$ (Figure 1). There is a tendency of increasing plant height along with the increasing of plant age and the slowing of the plant height improvement after 75 dap in all of the cotton strains. This happens because the plants have entered the generative phase so that the energy produced by the plant is used to the formation of flower and fruit. In line with the research result of Riajaya and Kadarwati (2013) where after 75 dap of cotton crops, there is no longer increase the height and width of the canopy significantly, since it is considered that the most photosynthate is used for fruit formation

Intercropping cotton crops shows higher comparing to monoculture cotton. This happens because the process of elongating the crop of intercropping cotton crops in the competition to get sunlight with maize with higher habitus. Similarly, Gonias et al. (2012) states that light interception in the cotton will decrease as the age of the plant increases. 
Furthermore, in the intercropping condition, the light interception accepted by cotton at the early growth stage will decrease. Light deficiency in young plant causes stems etiolation or elongation. Shaded condition cases the plant to grow longer as the plant attempts to find and get the sunlight (Sundary and Wahyu, 2012 ; Dewi, 2014).
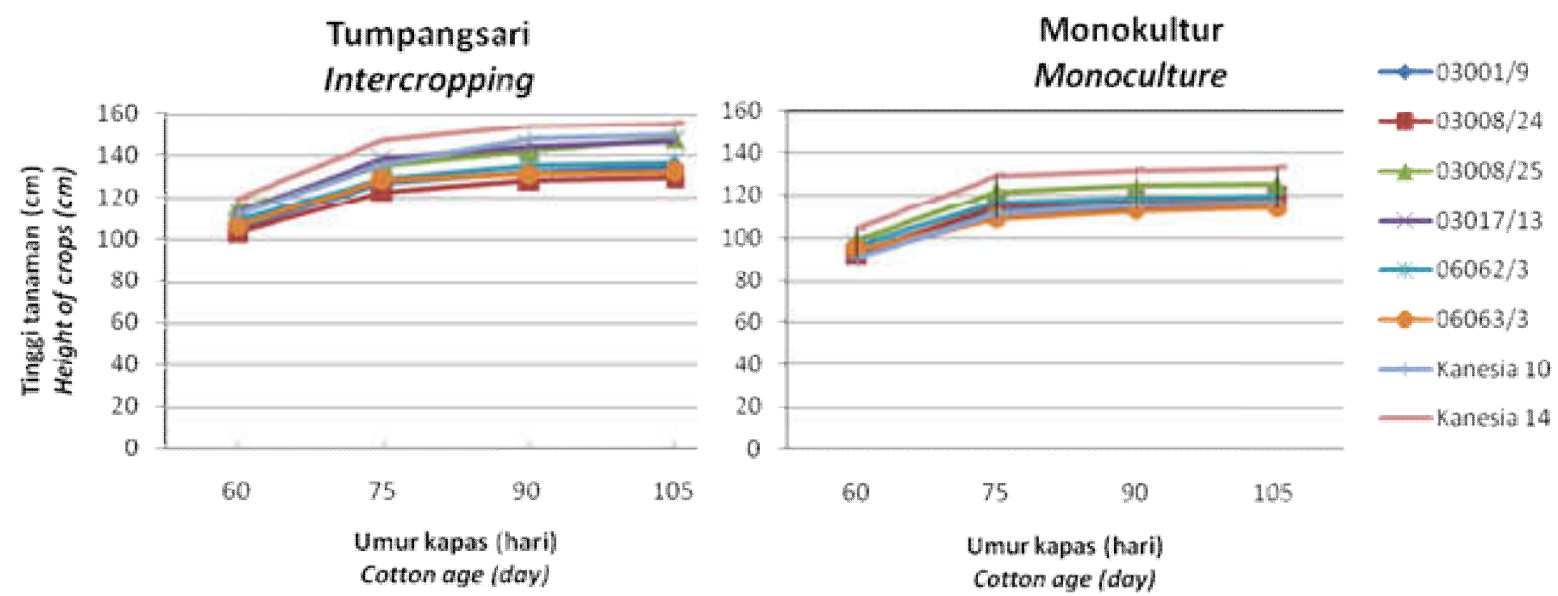

Figure 1 - Height of cotton crops at age 60-105 day after planting (dap)
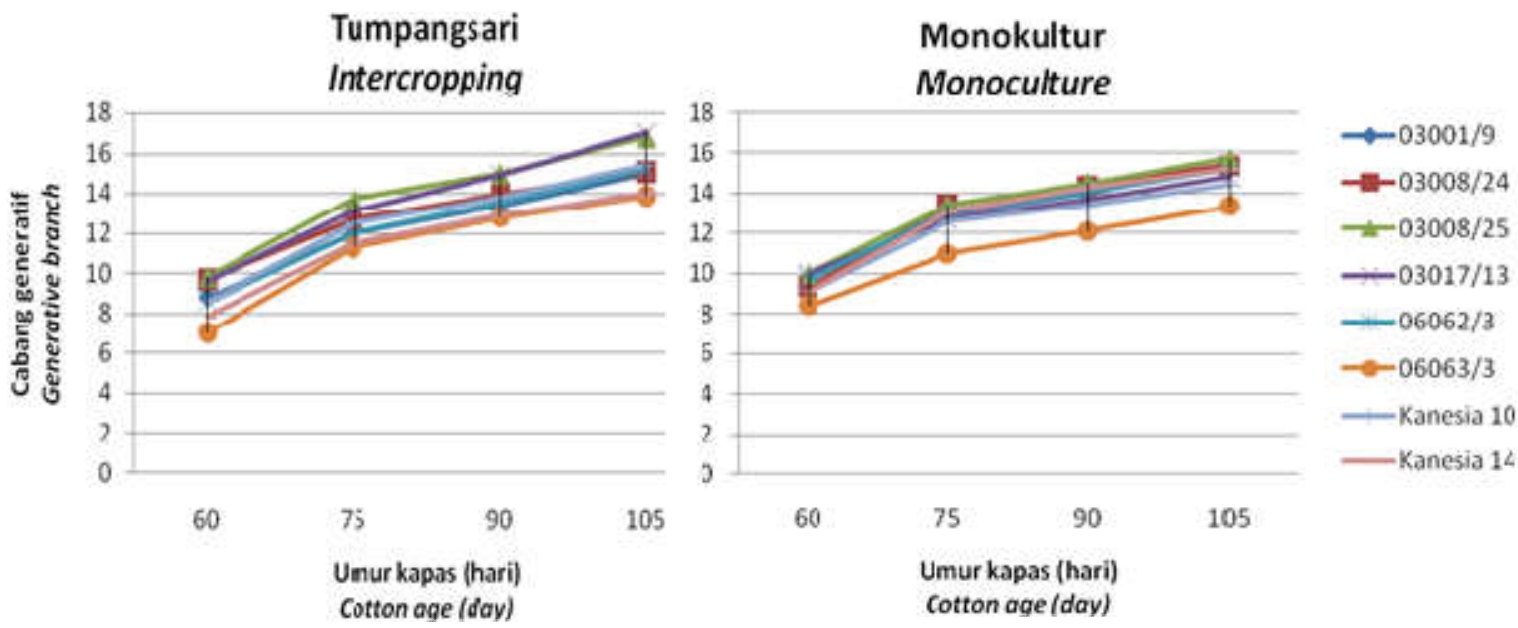

Figure 2 - Canopy width of cotton crops at age 60-105 dap

The width of the canopy of cotton corps at the age of 60 dap to 105 dap shows relatively the same. In the intercropping cotton corps, it can be seen that the canopy width ranging from $63.5 \mathrm{~cm}$ to $116.5 \mathrm{~cm}$ and the monoculture cotton corps ranging from $71.9 \mathrm{~cm}$ to $113.3 \mathrm{~cm}$. This suggests that $50 \mathrm{~cm}$ plant spacing between cotton and maize do not suppress the growth of the cotton corps canopy. The cotton canopy is still possible to grow sideways on the sidelines of the empty space between maize. Thus allowing the formation of higher flowers and fruits in intercropping cotton cultivation such as in monoculture cotton. The reduced canopy width and the number of the generative branches in the intercropping system resulting in a decrease in the number of fruits formed from 60 to 120 dap comparing to it monoculture (Riajaya and Kadarwati, 2013). The 6 new strains of the cotton and 2 comparative varieties (Kanesia 10 and 14) give up and side growth pattern during the growth phase (age 60 to 150 days) (Figure 1; Figure 2). This shows that the maize does not disturb the growth of all the experimented strains and varieties of the cotton. The reason is that all of the strains have normal type of leave and this has caused the early growth to be undisturbed and generally there will be an effect on the quality of the resulted fibers (Karademir et al, 2010; Safina et al., 2014). 

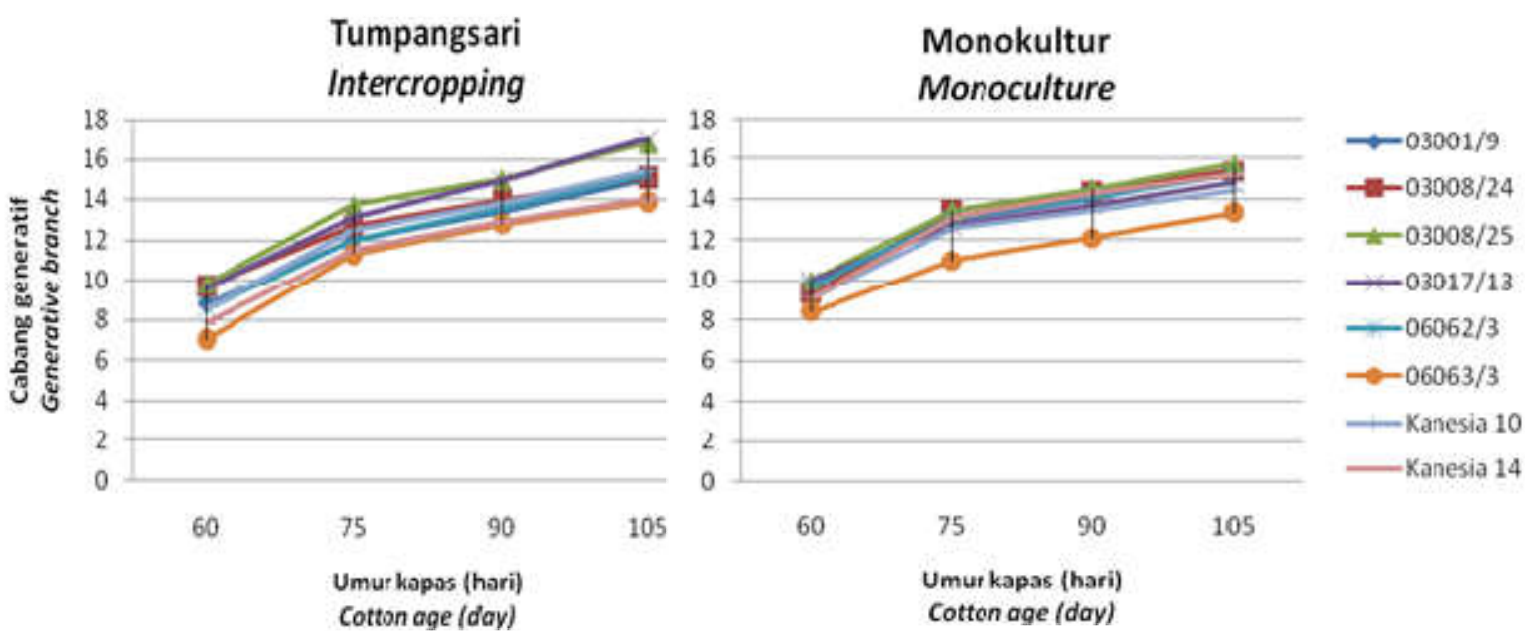

Figure 3 - The number of cotton generative branches at age 60-105 dap

At the age 60 dap, the generative branch of intercropping cotton has formed 7 to 9 branches while monoculture cotton will only form from 8 to 10 branches. There is an increase in the number of branches as the age of corps increase. The number of generative branches of the cotton is relatively good at the age of 105 dap both in intercropping or monoculture cotton. Although the range of the intercropping cotton is higher (13.9 - 17.0 branches) comparing to the monoculture cotton (13.3-15.7 branches). The growth pattern of the number of generative branches follows the pattern of the growth of corps height. The increase in the corps height is followed by the increase of the number of generative branches. The number of generative branches in the normal population ranges from $11.60-17.00 \mathrm{branch} / \mathrm{plant}$ (Riajaya et al., 2009; Riajaya and Kadarwati, 2013; Riajaya et al., 2009).

The number of fruit is one of the production components. In the intercropping cotton, there is a tendency of the increase in the number of fruits regularly started at the age 60 dap to 90 dap and then the number of fruits tend to stay and some were decreasing. Meanwhile, in the monoculture cotton, there is a tendency of the high improvement at the age of 60 dap to 75 dap and there is no significant increase in the number of fruits afterward (Figure 4). Zhang et al (2017) states that the dynamic of the cotton generative growth will be affected by the dynamic of the accepted temperature/heat and this will be different between monoculture cotton, intercropping cotton or relay planting. In addition, there is different nutrient absorption especially nitrogen between monoculture cotton, intercropping and relay planting (Zhang et al, 2008).
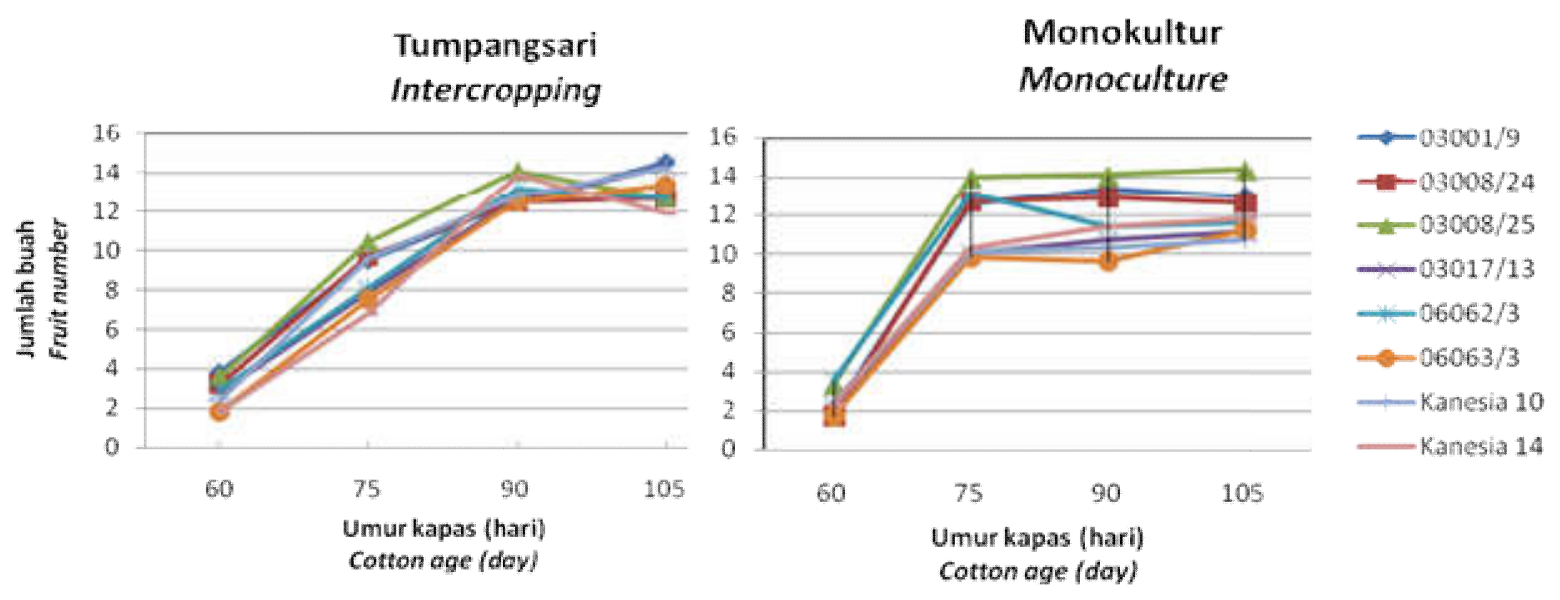

Figure 4 - The number of cotton fruit at age 60-105 dap 
The increase in the fruit formation of monoculture cotton after the age of 60 dap is quite higher comparing to intercropping cotton. This could happen due to the limited availability of groundwater so that the generative phase occurs quicker than the intercropping cotton which is still possible to grow upwards. At the monoculture cultivation, the water evaporation process in the groundwater is higher due to the canopy of the monoculture cotton which has not overlap between the corps. Thus, there is an open space that can cause the increase of groundwater evaporation. The presence of sandy soil with the low value of water holding capacity has increased the high of evaporation and percolation of groundwater. Lumbanraja (2012) states that water efficiency on the open ground is quite low, but it should be noted that groundwater evaporation does not happen only in the widely-open ground but also in every part of ground not covered by the leaves of the corp. This condition also increase the nutrient absorption in the intercropped plant (Blaise et al., 2005) resulting in high-quality formed fruits.

The component of cotton result consists of harvested fruit and the weight of the fruit. These two components will determine the last result of the cotton. In the experiment of the intercropping of cotton-maize, the number of harvested fruit ranges from 10.35-12.66 fruit/crop with the highest number of the fruit at the cotton strain 03017/13. Furthermore, in the monoculture ranges from 10.83-13.55 fruit/crop with the higher number of the fruit at the cotton strain $03008 / 25$. Variance analysis in the number of the fruit of intercropping or monoculture experiments shows no actual difference (Table 1).

There is a tendency to decrease the number of harvested fruit. This shows that not all of fruits that are formed can be harvested because it is affected by environmental factors such as groundwater availability and the presence of rain before the harvest. This will cause the fruit fail to bloom. The condition which is too dry when the cotton corps is about to enter the flowering and fruit formation phase can cause the flowers and fruits to fall. An excessive amount of water can cause deficiency due to the disruption of the pollination process, the fall of young fruit and the destruction of ready to harvest cotton fibers (DEWI, 2014). The number of fruits formed from the lower branches to the upper branches is not all harvested, due to the physiological loss or pest attack (Riajaya and Kadarwati, 2013).

Table 1 - The Effect of intercropping cotton and maize on yield components

\begin{tabular}{cccccc}
\hline \multirow{2}{*}{ No. } & \multirow{2}{*}{ Strain } & \multicolumn{2}{c}{ Number of harvested fruits } & \multicolumn{2}{c}{ Fruit weight $(\mathrm{g})$} \\
\cline { 2 - 5 } & & Intercropping & monoculture & Intercropping & monoculture \\
\hline 1 & $03001 / 9$ & $10.80 \mathrm{a}$ & $12.95 \mathrm{a}$ & $4.04 \mathrm{bc}$ & $4.49 \mathrm{ab}$ \\
2 & $03008 / 24$ & $11.76 \mathrm{a}$ & $12.90 \mathrm{a}$ & $4.17 \mathrm{abc}$ & $4.11 \mathrm{ab}$ \\
3 & $03008 / 25$ & $11.10 \mathrm{a}$ & $13.55 \mathrm{a}$ & $4.29 \mathrm{ab}$ & $4.10 \mathrm{~b}$ \\
4 & $03017 / 13$ & $12.66 \mathrm{a}$ & $11.13 \mathrm{a}$ & $4.05 \mathrm{bc}$ & $4.17 \mathrm{ab}$ \\
5 & $06062 / 3$ & $10.35 \mathrm{a}$ & $10.83 \mathrm{~b}$ & $4.11 \mathrm{bc}$ & $4.45 \mathrm{ab}$ \\
6 & $06063 / 3$ & $11.40 \mathrm{a}$ & $10.96 \mathrm{a}$ & $3.51 \mathrm{c}$ & $3.86 \mathrm{~b}$ \\
7 & Kanesia 10 & $12.36 \mathrm{a}$ & $12.05 \mathrm{a}$ & $4.86 \mathrm{a}$ & $4.98 \mathrm{a}$ \\
8 & Kanesia 14 & $10.95 \mathrm{a}$ & $11.36 \mathrm{a}$ & $4.33 \mathrm{ab}$ & $4.16 \mathrm{ab}$ \\
\hline
\end{tabular}

Note: numbers in the same column followed by the same letter are not significantly different with the DMRT 5\% test.

In the intercropping cultivation, the weight of cotton fruits ranges from $3.15 \mathrm{~g}-4.86 \mathrm{~g}$ while monoculture cotton ranges between $3.86 \mathrm{~g}-4.98 \mathrm{~g}$. The result of statistical analysis on the fruits weight parameter for intercropping cotton show that the comparison strain of Kanesia 10 and Kanesia 14 are not significantly different from strain 03008/24 and 03008/25 which means that they have higher cotton production potential comparing to other strains. Meanwhile in the statistical analysis in fruit weight for monoculture cotton show that the comparison strain is not significantly different from strain 03001/9, 03008/24, 03017/13, and $06062 / 3$ (Table 1). There is no higher strain fruits weight comparing to the comparison strain of Kanesia 10, both in intercropping and monoculture. Khan And Khaliq (2004) conclude that cotton intercropping and palawija plan will give component result such as different number of fruits depending on it variety. 
The result of seed cotton in intercropping cotton+maize ranges from $1,682.88 \mathrm{~kg} / \mathrm{ha}$ to $2470.01 \mathrm{~kg} / \mathrm{ha}$. This indicates the adoption 3:2 pattern corresponding to intercropping of cotton+maize. Appropriate cultivation density for prospect cotton strain is 3 lines of cotton and 2 lines of maize with the productivity level of $1,563.9 \mathrm{~kg} / \mathrm{ha}$ and maize $3,840,7 \mathrm{~kg} / \mathrm{ha}$ (RIAJAYA and KADARWATI, 2005). The highest result of seed cotton in intercropping cultivation pattern is reached by the strain $03017 / 13$ amounted to $2470.01 \mathrm{~kg} / \mathrm{ha}$ with corn yield of $2,001.54 \mathrm{~kg} / \mathrm{ha}$. The result of statistical analysis shows that there is no significant difference in strain 03017/13, 03001/9, 03008/24, 03008/25, Kanesia 10 and Kanesia 14 (Table 2).

Table 2 - Components of cotton yield and intercropping production of cotton and maize

\begin{tabular}{|c|c|c|c|c|c|c|c|}
\hline \multirow[t]{2}{*}{ No } & \multirow[t]{2}{*}{ Strains } & \multicolumn{2}{|c|}{ Intercropping yield (kg/ha) } & \multirow[t]{2}{*}{$\begin{array}{l}\text { Cotton yield of } \\
\text { monoculture } \\
(\mathrm{kg} / \mathrm{ha})\end{array}$} & \multicolumn{2}{|c|}{$\begin{array}{c}(\%) \\
\text { Decreasing yield to } \\
\text { monoculture }(\%)\end{array}$} & \multirow[t]{2}{*}{ NKL } \\
\hline & & Cotton & Maize & & Cotton & Maize & \\
\hline 1 & $03001 / 9$ & $2082.88 \mathrm{abc}$ & $1892.41 \mathrm{abc}$ & $2399.20 \mathrm{ab}$ & 13.18 & 41.83 & 1,48 \\
\hline 2 & $03008 / 24$ & $2329.72 a b$ & $2112.74 \mathrm{ab}$ & $2469.31 \mathrm{a}$ & 5.65 & 35.06 & 1,60 \\
\hline 3 & $03008 / 25$ & $2282.36 \mathrm{ab}$ & 1639.12 c & $2596.03 \mathrm{a}$ & 12.08 & 49.61 & 1,46 \\
\hline 4 & $03017 / 13$ & $2470.01 \mathrm{a}$ & $2001.54 a b c$ & $2412.96 a b$ & -2.36 & 38.47 & 1,68 \\
\hline 5 & $06062 / 3$ & $1936.16 \mathrm{bc}$ & $2117.76 \mathrm{ab}$ & $2052.12 b$ & 5.65 & 34.90 & 1,86 \\
\hline 6 & $06063 / 3$ & $1682.88 \mathrm{c}$ & $1747.23 \mathrm{bc}$ & $1786.77 \mathrm{~b}$ & 5.81 & 46.29 & 1,50 \\
\hline 7 & Kanesia 10 & $2362.9 a b$ & $2001.54 a b c$ & $2404.76 a b$ & 1.74 & 38.47 & 1,63 \\
\hline 8 & Kanesia 14 & $2256.63 \mathrm{ab}$ & $1936.68 \mathrm{abc}$ & $2104.23 a b$ & -7.24 & 40.47 & 1,68 \\
\hline & $\mathrm{KK}(\%)$ & 11.24 & 12.11 & 14.56 & & & \\
\hline
\end{tabular}

Note: numbers in the same column followed by the same letter are not significantly different with the DMRT 5\% test. NKL - value of land equality.

The high yield of seed cotton strain $03017 / 13$ is supported by the existence of the highest number of harvested fruits compared to other strains (Table 1). This shows that the strain $03017 / 13$ is capable to maintain the harvested fruits due to the sunlight and water competition during intercropping condition. The decreasing number and weight of the fruits in the cotton are more due to the decreasing of the efficiency of light interception for photosynthesis and the decreasing of net assimilation rate (Bednarz et al., 2000). So the strain $03017 / 13$ has a chance to be selected as a superior strain because it is able to adapt well to the intercropping condition. Szumigalski and Van Acker (2006) state that the efficiency of the Nitrogen absorption in the intercropping cotton is higher than monoculture cotton. Thus, the nutrient that is brought to the fruits will be higher resulting in bigger fruits in those strains.

Meanwhile, the highest yield of seed cotton in the monoculture cotton is obtained from strain $03008 / 25$ amounted to $2596.03 \mathrm{~kg} / \mathrm{ha}$ and the result of analysis of variance shows that there is no significant difference in the strain 03008/25, 03017/13, 03001/9, 03008/24, Kanesia 10 and Kanesia 14. The highest decrease value of intercropping seed cotton against the monoculture is $13.18 \%$ namely strain $03001 / 9$. Furthermore, the highest decrease of intercropping maize yield against monoculture ranges from $34.90 \%$ to $49.61 \%$. Intercropping is an agricultural cultivation by planting two or more crops on the same land and at the same time to increase production per unit of land (Hugar and Palled, 2008).

The average yield of monoculture seed cotton shows not many difference from the intercropping cotton yield that is equal to $102.72 \mathrm{~kg} / \mathrm{ha}$. It is suspected that experimental conditions with very high sand content (> 90\%) and monoculture crops have a lot of open space in the early phase of cotton growth resulting in high evaporation, which suppresses the growth and development of cotton. In all cotton strains and the comparison, varieties have a Land Equivalent Ratio (LER) of more than 1 with the highest value of 1.86 in the strain $06062 / 3$. Generally, LER value above 1 means the land used for intercropping is more efficient than monoculture (Riajaya and Kadarwati, 2014). The same result was found by Metwally et al. (2012) and Metwally et al (2015) on the Egyptian cotton where intercropping with the maize can give the result of NKL ranging between $1.45-1.98$ comparing to monoculture cotton. 
The highest acceptance Price of intercropping of cotton+maize is obtained from strain $03017 / 13$ with total acceptance of IDR 17,860,681 from cotton acceptance of IDR $11,856,048$ and maize of IDR $6,004,633$. While the second highest acceptance from stain $03008 / 24$ with total acceptance of IDR 17,520,879 from the cotton acceptance of IDR $11,182,656$ and corn of IDR $6,338,223$. The results statistical analysis in the acceptance of intercropping cotton show no significant difference in the strains 03017/13, 03001/9, 03008/24, 03008/25, Kanesia 10 and Kanesia 14 while the acceptance of maize show no significant difference on 03017/13, 03001/9, 03008/24, Kanesia 10 and Kanesia 14 (Table 3).

Table 3 - Acceptance of cotton, maize and intercropping of cotton+maize

\begin{tabular}{|c|c|c|c|c|c|c|}
\hline \multirow{3}{*}{ No } & \multirow{3}{*}{ Strains } & \multicolumn{4}{|c|}{ Acceptance (IDR) } & \multirow{3}{*}{$\begin{array}{l}\text { Increasing of } \\
\text { acceptance to } \\
\text { intercropping } \\
\text { (IDR) }\end{array}$} \\
\hline & & \multicolumn{3}{|c|}{ intercropping of cotton+maize } & \multirow{2}{*}{$\begin{array}{c}\text { Cotton } \\
\text { monoculture }\end{array}$} & \\
\hline & & Cotton & Maize & Cotton+maize & & \\
\hline 1 & $03001 / 9$ & $9,997,824 a b c$ & $5,677,220 a b c$ & $15,675,044 \mathrm{ab}$ & $11,516,160 \mathrm{ab}$ & $4,158,884$ \\
\hline 2 & $03008 / 24$ & $11,182,656 a b$ & $6,338,223 a b$ & $17,520,879$ a & $11,852,688$ a & $5,668,191$ \\
\hline 3 & $03008 / 25$ & $10,955,328 a b$ & $4,917,374 \mathrm{c}$ & $15,872,702 \mathrm{ab}$ & $12,460,944 a$ & $3,411,758$ \\
\hline 4 & $03017 / 13$ & $11,856,048$ a & $6,004,633 a b c$ & $17,860,681 \mathrm{a}$ & $11,582,208 a b$ & $6,278,473$ \\
\hline 5 & $06062 / 3$ & $9,293,568$ bc & $6,353,281 a b$ & $15,646,849 a b$ & $9,850,158 a b$ & $5,796,691$ \\
\hline 6 & $06063 / 3$ & $8,077,824 \mathrm{c}$ & $5,241,698$ bc & $13,319,522 b$ & $8,576,496$ b & $4,743,026$ \\
\hline 7 & K 10 & $11,342,064 a b$ & $6,004,633 a b c$ & $17,346,697 a$ & $11,542,848 a b$ & $5,803,849$ \\
\hline 8 & K 14 & $10,831,776 a b$ & $5,810,038 a b c$ & $16,641,814 \mathrm{a}$ & $10,100,304 a b$ & $6,541,510$ \\
\hline \multicolumn{2}{|r|}{ KK (\%) } & 11.24 & 12.11 & 9,02 & 14.90 & \\
\hline
\end{tabular}

Note: numbers in the same column followed by the same letter are not significantly different with the DMRT 5\% test. Cost of seed cotton is IDR 4,800/kg and maize is IDR 3,000/kg.

The highest total acceptance of intercropping cotton+maize above the comparison (kanesia 10 and kanesia 14) is obtained from the strain 03017/13 and 03008/24 amounted to IDR $17,860,681$ and IDR $17,520,879$. Where the result of the analysis of variance of the strain shows no significant difference with the comparison cotton Kanesia 10 and Kanesia 14 (Table 3), with the increased value of acceptance comparing to monoculture amounted to IDR 6.278.473 and IDR 5.668.191. Thus, the strain 03017/13 and 03008/24 are the prospect cotton strain of drought tolerant with high suitability in intercropping pattern with maize.

\section{CONCLUSION}

The prospect cotton strain with high suitability, when intercropped with maize, is $03017 / 13$ and $03008 / 24$ with the highest acceptance of IDR $17,860,681$ and IDR $17,520,879$ so that the increase of acceptance compared to monoculture amounted to IDR $6,278,473$ and IDR 5,668,191. The high acceptance is obtained from the production of seed cotton amounted to $2,470.01 \mathrm{~kg} / \mathrm{ha}$ and $2,329.2 \mathrm{~kg} / \mathrm{ha}$, maize production amounted to 2,001.54 $\mathrm{kg} / \mathrm{ha}$ and 2,112.74 kg/ha with Land Equivalent Ratio of 1.68 and 1.60. High cotton productivity is supported by the production component in the form of harvested fruits amounted to 12.66 and 11.76 fruit/plant and fruits weight of 4.05 and $4.17 \mathrm{~g} /$ fruit.

\section{ACKNOWLEDGEMENTS}

The author would like to thank all of the parties who have assisted the author in this research, especially Mr. Rifai'i as the head of KP. Asembagus and Mr. Sukarjo as the KP technician. Asembagus has assisted the author in conducting the research and observation.

\section{REFERENCES}

1. Basuki, T., M. Sahid, dan P.W. Yeyen. 2007. Pengembangan kapas di Indonesia dan permasalahannya. Prosiding Lokakarya Nasional Kapas dan Rami. Balai Penelitian Tanaman Pemanis dan Serat. Malang. Hal. 142-146. 
2. Bednarz, C.W., D.C. Bridges dan S.M. Brown. 2000. Analysis of coton yield stability across population densities. Agron J. 92(1):128-135.

3. Blaise, D, AN. Bonde, and RS. Chaudhary. 2005. Nutrient uptake and balance of cotton plus pigeonpea strip intercropping on rainfed vertisols of central India. Nutr Cycling in Agroecosyst. 73:135-1145

4. Dewi, ES. 2014. Aspek agronomi tanaman kapas. Dapur buku. Makasar. 67 p.

5. Dirjenbun. 2015. Statistik perkebunan indonesia 2014-2016 Kapas. Direktorat Jenderal Perkebunan. Jakarta.

6. Gonias, ED, 2012. Estimating light interception by cotton using a digital imaging technique. American J. Experimental Agric., 2(1):1-8

7. Hugar, H.Y. dan Y.B. Palled. 2008. Studies on maize-vegetable intercropping systems. Karnataka J. Agric. Sci. (21):162-164.

8. Karademir E. 2010. Relationship between Yield, Fiber Length and other Fiber-Related Traits in Adcanced Cotton Strains. Not. Bot. Hort. Agrobot. Cluj. 38(3):111-116

9. Khan, MB. 2004. Studies on intercropping Summerfodders in cotton. J. Res. Sci., 15(3):325-331

10. Kompas. 2016. Ekonomi: Apa saja bahan baku pembuatan uang rupiah?. http://bisniskeuangan.kompas.com/read/2016/12/19/193743126/apa.saja.bahan.baku.pe mbuatan.uang.rupiah. Verified in 20 Dec 2016.

11. Lumbanraja, P. 2012. pengaruh pemberian pupuk kandang sapi dan jenis mulsa terhadap kapasitas pegang air tanah dan pertumbuhan tanaman kedelai (Glycine max L.) var. willis pada tanah ultisol simalingkar. Jurnal IImiah Pendidikan Tinggi. 5(2):58-72

12. Metwally, AA. 2012. Effect of intercroppingcorn on Egyption characters. J. Cotton Sci., 16(4): 210-219,

13. Metwally, AA. 2015. Yield and Land Equivalent Ratio of Intercropping Maize with Egyptian cotton. JAAS Journal. 3(4):85-93

14. Riajaya, P.D. 2005. Pengaruh kerapatan tanam galur harapan kapas terhadap sistem tumpangsari dengan jagung. Jurnal penelitian tanaman industri. 11(2): 67-72.

15. Riajaya, P.D. 2013. Toleransi beberapa galur kapas pada tumpangsari dengan kacang hijau. Buletin tanaman tembakau, serat dan minyak industri 5(1):1-10

16. Riajaya, P.D. 2014. Kesesuaian galur-galur harapan kapas berdaun okra dalam sistem tumpangsari dengan kedelai. Buletin tanaman tembakau, serat dan minyak industri 6(1): 11-22.

17. Riajaya, P.D. 2009. Kesesuaian beberapa galur kapas berdaun okra pada sistem tanam rapat. Jurnal penelitian tanaman industri. 15(3):124-130.

18. Safina, SA. 2014. Productivity and Fiber Quality of Two EgyptionCottong Cultivar Under Solid and Intercropping Cultures With Maize, International J Agri Crop Sci., 7(11) : 778785

19. Sullivan, P. 2003. Intercropping principles and production principles. Agronomy Systems Guide. ATTRA Appropriate Technology Transfer for Rural Areas. Available at www.attra.ncat.org.12p. (Verified 25 Sep. 2013).

20. Sundari, T. 2012. Tingkat adaptasi beberapa varietas kedelai terhadap naungan. Penelitian pertanian tanaman pangan. 31(2):124-130

21. Szumigalski AR. 2006. Nitrogen yield and landuse efficiencyin annual sole crops and intercrops. Agron. J. 98:1030-1040

22. Zhang L. 2007. Cotton development and temperatur dynamics in relay intercropping with wheat. Field Crops Res. 103(3):178-188

23. Zhang L. 2008. Nitrogen economy in relay intercropping systems of wheat and cotton. Plant Soil 303:55-68 